\title{
PROSEDUR PEMBERIAN KREDIT PADA BANK NAGARI CABANG SIJUNJUNG
}

\author{
DHARMAWANTO, JHON FERNOS \\ Akademi Keuangan dan Perbankan "Pembangunan" \\ Jhonfernos@akbpstie.ac.id
}

\begin{abstract}
Bank Nagari yang berdiri pada tanggal 12 Maret 1962, atas kesadaran pemerintah daerah dan, tokoh-tokoh pengusaha swasta bahwa untuk dapat memacu gerak pembangunan daerah lebih cepat lai di Sumatera Barat, diperlukan adanya suatu lembaga keuangan yang berbentuk Bank yang secara khusus membantu pemerintah dalam melasanakan pembangunan di daerah. Bank Nagari cabang Sijunjung merupakan bank milik pemerintah daerah. Yang bertujuan memberikan kontribusi dalam mendorong pertumbuhan ekonomi dan kesjahteraan masyarakat, memenuhi dan menjaga kepentingan stack holder secara konsisten dan seimbang, dan seantiasa menjalankan prinsip untuk memenuhi tanggung jawab kepada pemilik dan karyawan.Sturuktur organisai Bank Nagari cabang Sijunjung dalam melakukan aktivitas usahanya merupakan struktur organisasi yang berbetuk organisasi garis dan staf.Bank Nagari Cabang sijunjung telah menyalurkan kredit sesuai dengan ketentuan dan prosedur yang telah ditetapkan, dengan tujuan untuk membantu masyarakat yang membutuhkan dana baik untuk keperluan konsumsi maupun untuk pengembnagan usaha nya.Untuk menghindari resiko yang mungkin terjadi pada kredit yang diberikan, Bank Nagari cabang sijunjung melakukan pengawasanmulai dari permohonan kredit, pengumpulan data, survey lapangan, pembuatan study kelayakan, realisasi kredit,aministrasi kredit hingga pelunasan kredit.Setiap prosedur yang dilakukan akan dilakukan penilaianyang mendalam untuk menilai kelayakan kredit yang diberikan dan untuk mengantisipasi terjadinya kredit macet atau kredit bermasalah. Dan apabila terjadi kredit macet atau kredit bermasalah bank Nagari cabang sijunjung akan melakukan prosedur-prosedur penyelesaian kredit bemasalah mulai dari, penaguhan rutin,menjual asset debitur sendiri,kerja sama dengan pihak lain, sampai dengan melelang agunan debitur
\end{abstract}

Keywords: Prosedur pemberian kredit

\section{PENDAHULUAN}

Dalam proses penyaluran kredit tentunya memiliki tahapan analisis yang tidak sederhana. Setelah mendapatkan nasabah yang prospek, pihak bank akan melakukan berbagai analisis seperti anlisis kuantitatif, kualitatif, ananlisis jaminan, serta cheking Bank Indonesia yang semuanya dilakukan untuk meminimalkan resiko. Analisis kredit meliputi latar belakang nasabah atau perusahaan, prospek usahanya, jaminan yang di berikan serta faktor-faktor lainya. Prosedur penyaluran kredit yang sehat ialah bahwa setiap calon debitur harus memberikan keyakinan dari berbagagi 
aspek bahwa dirinya dapat mengembalikan kredit (pokok dan bunga) tepat pada waktunya. Apabila karena sesuatu hal kemudian ternyata debitur tidak dapat memenuhi kewjibannya, maka bank akan menyita jaminan dalam nilai yang cukup untuk membayar hutang pokok dan bunganya. Melalui pernyataan tersebut dapat diambil kesimpulan bahwa bank harus teliti dalam menyalurkan kredit

. Dalam penyaluran kredit bank akan menghadapi berbagai macam situasi seperti jika debitur tidak membayar kewajibannya tepat pada waktunya, debitur menghilang dan sebagainya. Oleh sebab itu perlu dilakukan pengawasan terhadap pelaksaan kredit. Sebelum debitur memperoleh kredit lebih dahulu harus melalui tahapan-tahapan penilaian yaitu mulai dari permohonan calon debitur, penelitian data oleh bagian kredit, memeriksa kelengkpan data, wawancara, tinjauan langsung, ananlisa kredit, keputusan kredit, perjanjian kredit, dan peningktan agunan. Tahapan-tahapan dalam memberikan kredit ini dikenal sebagai prosedur pemberian kredit. Tujuan prosedur pemberian kredit adalah untuk memastikan kelayakan suatu kredit diterima atau ditolak

Bank Nagari Cabang Sijunjung adalah salah satu lembaga keuangan yang memberikan fasilitas kredit terhadap masyarakat. Masyarakat dapat memanfaatkan fasilitas layanan ini untuk meminjam uang yang nantinya dapat digunakan seuai dengan tujuan awal peminjaman. Keberadaan Bank Nagari Sijunjung sendiri sebagai suatu lembaga keuangan yang mempunyai fungsi memberikan pelayanan perbankan dan membantu dalam meningkatkan taraf hidup masyarakat memberikan manfaat yang besar baik dalam hal penghimpunan dana maupun penyaluran dana kepada masyarakat. Dengan adanya bank Nagari Cabang Sijunjung ini dapat memberikan manfaat yang optimal kepada masyarakat dalam rangka meningkatkan taraf hidup rakyat banyak.

Berdasarkan latar belakang yang telah diuraikan diatas, maka masalah yang akan dibahas dalam penelitian ini adalah bagaimana prosedur dalam pemberian kredit pada Bank Nagari Cabang Sijunjung.?

\section{LANDASAN TEORI}

Adapun pengertian bank menurut Undang-Undang RI Nomor 10 Tahun 1998 tentang Perubahan Undang-undang Nomor 7 Tahun 1992 tentang Perbankan adalah "Badan usaha yang menghimpun dana dari masyarakat dalam bentuk simpanan dan menyalurkannya kepada masyarakat dalam bentuk kredit dan/atau bentuk-bentuk lainnya dalam rangka meningkatkan taraf hidup rakyat banyak"

Dari pengertian di atas dapat di simpulkan bahwa usaha perbakan meliputi tiga kegiatan,yaitu menghimpun dana, menyalurkan dana, dan memberikan jasa bank lainnya. Kegiatan menghimpun dana,berupa mengumpulkan dana dari masyarakat dalam bentuk simpanan giro, tabungan dan deposito. Kegiatan menyalurkan dana, berupa pemberian pnjaman kepada masysrakat. Sedangkan jasa-jasa perbankan lainnya diberikan untuk mendukung kelancaran kegiatan utama tersebut.

Menurut Undang-undang pokok perbankan nomor 7 tahun 1992 sebagaimana telah di ubah dengan undang-undang RI nomor 10 tahun 1998 tentang perbankan maka jenis perbankan maka jenis perbankan terbagi menjadi dua jenis, yaitu:

1. Bank umum

Yaitu bank yang melaksanaka kegiatan usaha secara konvensional dan atau berdasarkan prisip syariah yang dalam kegiatannya memberikan jaa dalam lalu lintas pembayaran. Institusi keuangan yamg berorientasi laba. Untuk 
memperoleh laba tersebut bank umum melaksanakan fungsi intermediasi. Karena di izinkan mengumpulkandana dalam bentuk deposito, bank umum di sebut juga sebagai lembaga keuangan depositori. Berdasrkan kemmpuannya menciptakan uang (giral), bank umuma dapat juga disebut sebagai bank umum pencipta uang giral.

2. Bank perkreditan Rakyat (BPR)

Yaitu bank yang melaksanakan kegiatan usahannya secara konvensional atau berdasarkan atau prinip syariah yang dalam kegiatannya tidak memberikan jasa dalalm lalu lintas pembayaran.

Berdasrkan Undang-Undang No. 17 tahun 1992 dan telah diperbarui menjadi Undang-Undang No. tahun1998 pasal 1 ayat 11 yang dimaksud dengan kredit adalah penyediaan uang atau tagihan yang dapat di persamakn dengan itu, berdasarkan persetujuan atau kesepakatan yang mewajibkan pinjaman meminjam antar bank dengan pihak lain yang mewajikan pihak peminjam untuk melunasi hutangnya setelah jangka waktu tertentu dengan jumlah bunga imbalan atau pembagian hasil keuntungan.

Didalam pemberian kredit terdapat dua pihak yang langsung berkaitan. Yang pertama pihak pemberi kredit (reditr) yaitu pihak yang mempunyai kelebihan dana dan yang kedua pihak penerima kredit (kreditur) yaitu yang membutuhkan dana.

Bank merupakan lembaga financial intermediary aktif sebagai perantara dari kedua pihak terseut. Bank menghimpun dana dari masyarakat yang kelebihan dana dalam betuk simpanan dan kemudian mnyalurkanya kemabali kepada masyarakat dalam bentuk kredit atau yang di persamakan dengan itu secara efektif melalui sektor usaha yang produktif.Sebagaimana lembaga perantara bank di harpkan mmpu turut serta meningkatkan taraf hidup kehidupan masyarakat secara khusus dan peningkatan perekonomian secara umum.

Fungsi kredit perbankan dalam kehidupan perekonomian dan perdagangan antara lain sebgai berikut:

1. Kredit pada hakikatnya dapat meningkatkan daya guna uang

2. Kredit dapat meningkatkan peredaran dan lalu lintas uang

3. Kredit pada hakikatnya dapat meningkatkan daya guna barang

4. Kredit sbagai salah satu kebjakan pemerintah untuk stabiliasi perekonomian

5. Kredit dapat meningkatkan kegiatan usaha

6. Kredit dapat meningkatkan pemeratan pendapatan

7. Kredit sebagai alat hubungan

Tujuan pokok dari pemberian kredit oleh suatu bank adalah untuk:

1. Turut mensukseskan program pemerintah dibidang ekonomi dan pembangunan.

2. Meningkatkan aktivitas ekonomi atau kegiatan perusahaan agar dapat menjalankan fungsinya guna menjamin terpenuhinya kebutuhan masyarakat.

3. Memperoleh laba agar kelangsungan hidup bank dapat terjamin mengingat pemberian kredit merupakan kegiatan utama bank dan penghsilan pokok bank.

Unsur-unsur yang terdapat dalam pemberian kredit antara lain:

1. Kepercayaan (trust) 
Yaitu keyakinan si pemberi kredit bahwa yang diberikannya benar-benar akan diterimanya kembali dalam jangka watu tertentu dimasa yang akan datang.

2. Waktu (time)

Yaitu suatu masa yang memisahkan antara pemberian prestasi dengan kontra prestasi yang akan diterimanya pada masa yang akan datang.

3. Tingkat resiko

Yaitu suatu tingkat resiko yang akan dihadapi sebagai akibat adanya jangka waktu yang memisahkan antara pemberian prestasi dengan kontra prestasi yang akan diterimanya di kemudian hari. Semakin lama kredit yang dibeikan semakin tinggi pula tingkat resikunya, karena sejauh masi terdapat unsur ketidaktentuan yang tidak dapat dipehitungkan. Inilah yang menyebabkan timbulnya unsur resiko. Dengan adanya unsur ini maka timbulah dalam pemberian kredit.

4. Prestasi

Restasi atau objek kredit tidak saja di berikan dalam bentuk uang, tetapi juga dapat berbentuk barang atau jasa.

Jenis-jenis kredit yaitu:

1. Kredit investasi

Merupakan kredit jangka menengah dan pnjang yang ditujukan unuk modal usaha pembelian sarana alat produksi dan atau pembelian barang modal berupa aktiva tetap atau investasi.

2. Kredit modal kerja

Merupakan kredit jangka pendek atau menengah yamh di tujukan untuk membeikan modal usaha seperti atara lain pembelian bahan baku atau brang yamh akan diperdagangkan.

3. Kredit konsumsi

Merupakan kredit untuk perorngan yang ditujukan untuk pembelian suatu barang yang di gunakan untuk kepentingan perseorangan (pribadi).

4. Kredit usaha tanpa bunga dan angguran

Merupakan kredit yang di sediaka khusus untuk usaha kecil dan menengah. Kredit semacam ini sangat merigankan bagi pengusaha.

Di dalam pemberian kredit, dapat di tinjau prinsip-prinsip dalam pemberian kredit,yaitu:

1. Prinsip kepercayaan

Karena kredit berarti kepercayaan, maka dalam hal ini pemberian kredit pun haruslah ada kepercayaan dari kreditur bahwa dana tersebut akan bermanfaat bagi debtur dan kepercayaan dari kreditur bahwa debitur dapat mengembalikan dana tersebut dalm jangka waktu tertentu.

2. Prinsip ke hati hatian

Agar kredit atau pembiayaan tidak menjadi macet, maka dalam memberikan kredit atau pembiayan haruslah cukup kehati hatian dari pihak kreditur dengan menganalisis dan mempertimbangkan semua faktor yang relevan. Untuk itu perlu di lakukan suatu pengawasan terhadap suatu pemberian kredit.

3. Prinsip sikronisasi

Prinsip sikronisasi (matching) merupakan prinsip yang mengharuskan adanya sinkronisasi antara pinjaman dan asset/income dari debitur. Misalnya, jangan memberikan kredit/pembiayaan jamgka pendek untuk keperluan investasi jangka panjang. 


\section{Prinsip kesamaan valuta}

Dalam hal ini yang di maksudkan adalah sedapat-dapatnya ada kesamaan antara jenis valuta untuk kredit/pemiayaan dan penggunaan dana tersebut, sehingga resiko fluktuasi mata uang dapat dihindari.

5. Prinsip perbandingan amtara pinjman dan asset

Dalam hal ini yang di maksud adalah perbandingan antara pinjaman dan modal dalam rasio yang wajar.

6. Prinsip perbandingan antara pinjaman dan asset

Dalam hal ini yang di maksud adalah, perbandingan antara pinjaman dan asset dalam rasio yang wajar.

Selain itu menurut Dendawijaya(2008:91), dasar penilaian kredit yang sering dipakai didunia perbankan dikenal demgan prinsip 5C, yang terdiri dari.

1. Character (watak)

Yaitu suatu keyakinan bahwa sifat atau watak dariorang-orang yang diberikan kredit benar-benar dapat dipercaya, hal ini tercermin dari latar belakang debitur baik yang bersifat latar belakang pekerjaan besifat pribadi seperti gaya hiduo, kebiasaan, dan social tandingnya.

2. Capacity (kapasitas)

Untuk melihat nasabah dalam kemampuannya dalam bidang bisnis dihubungkan dengan pendidikannya, kemamouan bisnis juga diukur dengan kemampuannya dalam memahami tentang ketentuan-ketentuan pemerintah. Begitu pula dengan kemampuannya dalam menjalankan usahanya selama ini. Pada akhirnua akan terlihtat kemampuannya dalam mengembalikan kredit yang di salurkan.

3. Cpital (pemodalan)

Untuk melihat penggunaan modal apakah efktif atau tidak, diihat dari laporan keuagan (neraca dan laporan laba rugi) dengan melakukan pengukuran seperti likuiditas, rentabilitas, dan ukuran lainnya. Capital juga harus dilihat dari sumber mana saja modal yang ada sekarang ini.

4. Collecteral (agunan/jaminan)

Merupakan jaminn yang di berikan calon nasabah baik bersifat fifsik maupun non fifsik. Jaminan hendaknya melebuhi jumlah kredit yang diberikan, jaminan juga harus diteliti keabsahannya sehingga jika terjadi suatu masalah, maka jamian ang dititipkan akan dapat dipergunakan.

5. Cindition of economic (kondisi ekonomi)

Dalam menilia kredit hendaknya juga dinilai kondisi ekonomi dan poitik sekarang an dimasa yang akan datang sesuai sector masing-masing serta prospek usaha yang debitur jalnkan. Penilaian prospek bidang usaha yang di biayai hendaknya benar-benar memiliki prospek yang baik kemungkinan kredit tersebut bermasalah relative kecil.

Selain 5C diatas, ada juga prinsip lain dalam memberikan kredit yaitu yang biasa disebut 4P, yaitu:

1) Personality yaitu bank mencari data tentang kepribadian si peminjam seperti riwayat hidupnya (kelhiran, pendidikan, pengalaman usaha/pekerjaan dan sebagainya), hobinya, keadaan keluarga (istri,anak), social standing (pergaulan dalam masyarakat tentang sipeminjam), serta hal-hal lain yang erat hubungannya kepribadiann si peminjam. 
2) Purpose yaitu mencari data tentang tujuan atau kepeluan penggunaan kredit. Apakah akan digunakannya untuk bergadang, berproduksi atau atau membeli rumah. Dan apakah tujuan pengguaan kredit itu sesuai dengan line of business kredit bank yang bersangkutan . Misalnya, keperluan/tujuan kredit untuk keperluan perkapalan sedangkan line of busuness bank justru dalam bidang petanian.

3) Prospect yaitu harapan masa depan dari bidang usaha atau kegiatan usaha sipeminjam. Ini dapat diketahui dari perkembangan usaha si peminjam selama beberapa bulan/tahun, perkembangan keadaan ekonomi perdagangan, keadaan ekonomi/perdagangan sector usaha peminjam, kekuatan keuangan perusahaan yang di buat dari erning power (kekuatan pendaoatan/kekuatan)masa lalu dan perkiraan masa mendatang.

4) Payment yaitu mengetahui bagaimana pembayaran kembali pinjaman yang diberikan. Hal ini dapat diperoleh dari perhitungan tentang prospek kelancaran penjualan dan pendapatan sehingga dapat diperkirakan kemampuan pengambilan pinjaman ditinjau dari waktu serta waktu pengambilannya.

\section{METODE PENELITIAN}

Didalalam pengumpulan data dan bahan untuk melakukan penelitian ini digunakan metode- metode pengumpulan data, sebagai berikut :

1. Metode pengumpulan data

a. Studi lapangan ( field research)

Peninjauan langsung ke objek penelitian yang dipilih untuk meneliti hasil data primer, penelitian langsung ke lapangan ini akan dapat membantu penulis untuk melengkapi data yang diperlukan. Adapun cara riset lapangan ini adalah dengan mewawancarai langsung pihak-pihak yang berkepentingan dalam hal ini adalah perusahaan atau instansi yang terkait.

a. Studi perpustakaan ( library research)

Penelitian yang dilakukan keperpustakaan berupa buku-buku ilmiah dan tulisantulisan yang berhubungan dengan pembahasan yang dilakukan.

2. Metode Analisa Data

Dalam menganalisa data, penulis menggunakan metode analisa kualitatif sebagai metode penelitian yang menjelaskan secara deskriptif mengenai prosedur pemberian kredit pada Bank Nagari Cabang Sijunjung.

\section{HASIL DAN PEMBAHASAN}

Sebelum debitur memperoleh kredit terlebih dahulu harus melalui tahapantahapan penilaian mulai dari pengajuan proposal kredit dan dokumen-dokumen yang di perlukan, pemeriksaan keaslian dokumen, analisis kredit sampai dengan kredit di cairkan.Tahapan-tahapan dalam memberikan ini kita kenal dengan prosedur pemberian kredit. Tujuan proseur pemberian kredit adalah untuk memastikan kelayakan suatu krdit di terima. Dalam menntukan kelayakan suatu kredit maka dalam setiap tahap selalu dilakukan penilaian yang mendalam.

Pada bank Nagari cabang Sijunjung prosedur pemberian kredit kepada nasabah adalah sebagai berikut: 
1. Calo debitur mengajukan atau mengisi permohonan lengkapdengan dokumendokumen,data-data, atau syarat-syarat yag ditentukan oleh bank Nagari cabang Sijunjung.

2. Selanjutnya bank Nagari akan mengola data awal yang ada.

3. Pihak bank Nagari akan melakukan survei lapangan, yaitu ditinjau langsung kerumah calon debitur

4. Selanjutnya dilakukan rekomendasi kredit atau anlisis kredit, diprosen ini akan dinilai apakah calon debitur layak diberikan kredit atau tidak, yang akan dinilai adalah:

a. Kelayakan usaha, apakah usaha yang dijalankan layak diberikan kredit.

b. Nilai agunan,apakah nilai agunan yang dijaminkan sesuai dengan jumlah pinjaman yang diajukan.

5. Apabila usaha yang dijalankan dinilai layak oeleh analisis kredit, maka appraisal kredit akan diajukan kepada pimpinan bank Nagari cabang Sijunjung atau pimpinan divisi bagian kredit.

6. Apabila disetujui oleh pimpinan, calon debitur akan diberitahu dengan menelfon nasabah dan disuruh datang ke bank untuk menandatangani surat perjanjian kredit.

7. Selanjutnya akan dilakuan realisasi kredit,pengikatan agunan dan pencairan kredit.

8. Setelah pencairan kredit, bank Nagari cabang sijunjung akan melakukan monitoring atau pengawasan terhadap kredit yang diberikan tersebut.

Tujuan utama pemberian fasilitas kredit adalah sebagai berikut:

1. Untuk memabantu nasabah yang membutuhkan dana, baik dana untuk keperluan konsumsi ataupun untuk menjalankan atau mengembangkan usahanya, sesuia dengan jenis kredit yang diajukan dan tujuan mengajukan permohonan kredit.

2. Pengembang usaha nasabah,bank dapat mendorong usaha masyarakat dengan memberikan fasilitas kredit. Kredit yang diberikan dapat berupa kredit dana investasi maupun dana untuk modal kerja. Kredit yang diterima oleh nasabah baik perorangan maupun lembaga dapat digunakan untuk pengembangan dan perluaasan usahanya.

3. Peningkatan peekonomian, kredit mempunyai pengaruh terhadap perekonomian negara. Dengan penyaluran kredit dapat meingkatkan pembangunan diberbagai sektor. Kredit investasi dan modal kerja akan memperluas usaha yang berdampak pada peningkatan kebutuhan tanaga kerja. Artinya kredit dapat mengurangi pengangguran. Kredit yang disalurkan dapat menigkatkan konsumsi terhadap barang dan jasa. Artinya ada peningkatan gross domestic product.

Kredit yang diberikan oleh bank memiliki ketentuan atau persyaratan yang harus dipenuhi oleh calon debitur sebelum mendapatkan kredit dari bank, persyaratan ini harus dipenuhi seluruhnya oleh calon debitur supaya bank bisa mengetahui kelayakan calon debitur diberikan kredit. Ketentuan pokok pemberian kredit yang harus dipenuhi oleh calon debitur di bank Nagari cabang sijunjung adalah

1. Persyaratan dokumen permohonan krdit 
a. Foto copy kartu tanda penduduk/paspor/SIM dan kartu keluarga.

b. Pas foto sebanyak 2 lembar.

c. Fotocopy akta pendirian berikut seluruh perubahannya.

d. Fotcopy perizinan uasaha: SIUP,SIN,TDP.

e. Fotocopy dokumen jaminan (sertifikat tanah,BPKB, surat toko,lainnya).

f. Data-data keuangan (neraca dan laporan laba rugi).

g. Dokumen pendukung lainnya. NPWP.

2. Identifikasi data

Identifikasi data permohonan kredit dilakukan dengan mempedomani buku pelaksaan kredit tentang proses persetujuan pemberian krdit.

3. Dipertmbangkan untuk dilanjutkan

Setelah diidentifikasi, maka selanjutnya pihak bank akan melakukan pertimbangan. Apabila calon nasabah tersebut di luar kriteria yang di tentukan oleh bank, maka permohonan langsung di tolak. Sedankan apabila calon nasabah termasuk dalam kriteria yang dapat dilayani, maka permohonan akan dipertimbangkan untuk dilanjutka.

4. Kelengkapa data

Dalam tahap ini semua data tentang calon debitur akakn diperiksa kesliannya.

5. Wawancara

Dalam tahap ini pihak bank langsung mewawancarai calon debitur. Selain pertimbangan data melalaui tulisan, pertimbangan melalui lisan pun diperlukan. Ini diperlukan untuk mengetahui Pengukuran Resiko Operasional.

6. Tinjauan ketempat lokasi

Dalam tahap ini pihak bank melakukan tinjauan langsung kelokasi calon debitur, pihak bank akan mengidentifikasi kesesuian data antara pernyataan si pemohon dengan fakta dilapangan.

7. Analisis kelayakan kredit

Analisis kredit dilakukan untuk menilai kelayakan suatu permohonan kredit dan memperkirakan factor-factor risiko yang aka timbul berkaitan dengan pemberian kredit. Untuk mengetahui seberapa jauh resiko yang mungkin akan timbul maka dilakukan analisis aspek-aspek dalalm pemberian kredit.Aspek minimal yang harus dianalisis pada rekomendasi kredit antara lain:
a. Data pokok
b. Aspek hokum
c. Aspek manajemen
d. Aspek teknis
e. Aspek pemasaran
f. Aspek keuangan
g. Aspek agunan
h. Aspek sosial ekonomi
i. Aspek dampak lingkungan

Kredit bermasalah adalah kredit yang memngalami kesulitan dalam menyelesaikan kewajiban baik dalam bentuk pembayaran kembali pokoknya dan atau pembayaran bunga, denda keterlambtan (kondisional tergantung sutuasi) menjadi beban debitur yang besangkutan. Penyebab terjadinya kredit macet atau kredit bermasalah adalah 
1. Faktor intern
a. Ananlisis kredit atau krdit yng tidak akurat
b. Lemahnya pengawasan dan monitoring

2. Faktor ekstern

a. Usaha debitur mengalami kegagalan atau mengalami penurunan

b. Permasalahan keluarga debitur

Penyelesaian kredit bermasalah

1. Dilakukan penagihan rutin kepada debitur

2. Nasabah diberi surat tunggakan, surat peringatan I,surat peringatan II, dan surat peringatan III

3. Jika belum ada penyelesian yang kongkrit dari pihak debitur, maka proses selanjutnya piahk bank akan bekerja sama dengan pihak lain

4. Jika debitur bersedia, debitur menjual asset nya sendiri,seperti tanah,ruamah,toko dan lain-lain

5. Jika debitur tidak bersedia asset nya maka langkah terakhir yang dilakukan bank adalah melelang agunan kredit untuk menyelesaikan tunggakan kredit debitur

\section{SIMPULAN}

Berdasarkan uraian pada bab-bab sebelumnya, maka dapat diambil kesimpulan sebagai berikut:

1. Bank Nagari yang berdiri pada tanggal 12 Maret 1962, atas kesadaran pemerintah daerah dan ,tokoh-tokoh pengusaha swasta bahwa untuk dapat memacu gerak pembangunan daerah lebih cepat lai di Sumatera Barat, diperlukan adanya suatu lembaga keuangan yang berbentuk Bank yang secara khusus membantu pemerintah dalam melasanakan pembangunan di daerah.

2. Bank Nagari cabang Sijunjung merupakan bank milik pemerintah daerah. Yang bertujuan memberikan kontribusi dalam mendorong pertumbuhan ekonomi dan kesjahteraan masyarakat, memenuhi dan menjaga kepentingan stack holder secara konsisten dan seimbang, dan seantiasa menjalankan prinsip untuk memenuhi tanggung jawab kepada pemilik dan karyawan.

3. Sturuktur organisai Bank Nagari cabang Sijunjung dalam melakukan aktivitas usahanya merupakan struktur organisasi yang berbetuk organisasi garis dan staf.

4. Bank Nagari Cabang sijunjung telah menyalurkan kredit sesuai dengan ketentuan dan prosedur yang telah ditetapkan, dengan tujuan untuk membantu masyarakat yang membutuhkan dana baik untuk keperluan konsumsi maupun untuk pengembnagan usaha nya.

5. Untuk menghindari resiko yang mungkin terjadi pada kredit yang diberikan, Bank Nagari cabang sijunjung melakukan pengawasanmulai dari permohonan kredit, pengumpulan data, survey lapangan, pembuatan study kelayakan, realisasi kredit,aministrasi kredit hingga pelunasan kredit.

6. Setiap prosedur yang dilakukan akan dilakukan penilaianyang mendalam untuk menilai kelayakan kredit yang diberikan dan untuk mengantisipasi terjadinya kredit macet atau kredit bermasalah.

7. Dan apabila terjadi kredit macet atau kredit bermasalah bank Nagari cabang sijunjung akan melakukan prosedur-prosedur penyelesaian kredit bemasalah mulai dari, penaguhan rutin,menjual asset debitur sendiri,kerja sama dengan pihak lain, sampai dengan melelang agunan debitur 


\section{DAFTAR PUSTAKA}

Abdul Bay, Marhanis, 1999, Hukum Prebankan di Indonesia, cetakan kelima, Edisi Kedua, Angkasa, Bandung.

Alanshari, F., \& Marlius, D. (2018). Prosedur Pemberian Kredit KPR Pada PT. Bank Tabungan Negara (Persero) TBK Cabang Pembantu Bukittinggi. https://doi.org/10.31227/osf.io/rsfhc

Amelia, L., \& Marlius, D. (2018). Pengendalian Kredit Dalam Upaya Menciptakan Bank Yang Sehat Pada PT. Bank Pembangunan Daerah Sumatera Barat Cabang Utama Padang. https://doi.org/10.31227/osf.io/kpc64

Bambang Tri Cahyono, (1983), Manajemen Prekreditan, Ananda, Yogyakarta

Denda Wijaya, Lukman (2008), Manejemen Perbankan, Gramedia Indonesia, Jakarta.

Djumhana, Muhamad, (2000), Hukum Perbankan di Indonesia, Bandung : PT Citra Aditya Bakti.

Ekonisia, (2003), Manajemen perbankan, PT. Raja Grafindo Persada, Jakarta.

Kasmir, (2006), Manajemen perbankan, PT. Raja Grafindo Persada, Jakarta.

Kasnir, (2011), Bank dan Lembaga Keuangan lainnya, PT. Raja Grafindo Persada, Jakarta.

Thomas Suyatno dkk, (1995), “Dasar-Dasar Perkreditan“, Edisi Keempat, PT. Gramedia Pustaka Utama, Jakarta.

Shanjaya, A. R., \& Marlius, D. (2017). Peranan Laporan Keuangan Dalam Kebijaksanaan Pemberian Kredit Kepada Calon Nasabah Pada PT. BPR Batang Kapas. https://doi.org/10.31227/osf.io/uxmg6

Undang-Undang No. 10 tahun 1998, “Tentang Perbankan”, Sinar Grafika, Jakarta.

Warman Djohan, (2002), Kredit Bank, PT. Mutiara Sumber Widya, Jakarta. 